\begin{tabular}{|l|l|}
\hline тренинг, родительские & $\begin{array}{l}\text { собой неповторимую личность, а значит, требует к себе особых, } \\
\text { индивидуальных способов взаимодействия и форм общения: не навязывай, } \\
\text { а предлагай; } \\
\text { не принуждай, а побуждай; не приказывай, а проси; не поспеши, но и не } \\
\text { опоздай; не отказывай, а предложи другой способ решения } \\
\text { проблемы;развивай в ребенке дух сотрудничества, а не покорности; исходи } \\
\text { из интересов ребенка; опирайся на собственную активность ребенка, } \\
\text { которая будет являтьсяисточником его эмоциональной включенности. }\end{array}$ \\
\hline $\begin{array}{l}\text { Диагностическое } \\
\text { обследование педагогов } \\
\text { и родителей }\end{array}$ & Анализ эффективности проводимых мероприятий. \\
\hline
\end{tabular}

Мы предполагаем, что реализация данных мероприятий будет способствовать решению задачи по определению индивидуального подхода педагогов к детям и приблизит к основополагающему положению Федерального государственного образовательного стандарта дошкольного образования (ФГОС ДО) - индивидуализации развития и обучения детей [4].

$$
* * *
$$

1. Изотова Е.И. Психологическая служба в образовательном учреждении. - М.: Издательский центр «Академия», 2009. - 288 с.

2. Петровский, В.А., Калиненко, В.К., Котова, И.Б. Личностно-развивающее взаимодействие. - Ростовна-Дону: РИО АО «Цветная печать» 1995. - 85 с.

3. Русина Е. И. Педагогические условия личностно- ориентированного взаимодействия с детьми старшего дошкольного возраста в процессе познавательной деятельности: дис... канд. пед. наук: 13.00.01/ - М.: МПГУ, 2005. - 205 с.

4. Федеральный государственный образовательный стандарт дошкольного образования. - М: УЦ Перспектива, 2014. - 32 с.

\title{
Мигунова Ю.С. \\ Психологические особенности совместной деятельности членов курсантского коллектива подразделений ГПС МЧС России в процессе исполнения ими своих обязанностей
}

ФГБОУ ВО Ивановская пожарно-спасательная академия ГПС МЧС России

(Россия, Иваново)

doi 10.18411/gq-30-11-2017-24

idsp 000001:gq-30-11-2017-24

\section{Аннотация}

В статье рассмотрены проблемные аспекты формирования межличностных отношений в курсантских подразделениях ГПС МЧС России. Обозначены векторы влияния трудностей учебно-служебной деятельности на субъективную удовлетворенность членов курсантского коллектива.

Ключевые слова: межличностные отношения, психологические аспекты, субъективная удовлетворенность, учебно-служебная деятельность.

\section{Abstract}

The article considers problem aspects of formation of interpersonal relations the cadet units of state fire service of EMERCOM of Russia. The labeled vectors of the influence of the difficulties of educational work on the subjective satisfaction of the members of the cadet team.

Keywords: interpersonal relations, psychological aspects, subjective satisfaction, teaching and service activities. 
Деятельность учебных подразделений ГПС МЧС России направлена на профессионально-личностное развитие курсантов, необходимое для успешного выполнения профессиональных функций и задач.

Продуктивность учебно-служебной деятельности курсантов, а также наличие их субъективной удовлетворенности во многом зависят от сложившейся в подразделении социально-психологической обстановки и системы межличностных отношений. Коллектив учебного подразделения с высоким уровнем межличностных отношений характеризуется сплоченностью, дисциплинированностью, исполнительностью и положительной тенденцией формирования морально-нравственных качеств личности. Коллектив учебного подразделения с низким уровнем межличностных взаимоотношений между курсантами приводит к нарушению курсантской дисциплины, неуставным взаимоотношениям, дезорганизации управления, конфликтности и разобщенности [2].

Негативные взаимоотношения оказывают деструктивное влияние на профессионально-личностное развитие курсантов и снижают уровень субъективной удовлетворенности. Подготовка специалистов в области пожарной охраны, исходя из современных требований, должна опираться на конструктивные взаимоотношения между командным составом, младшими командирами и непосредственно курсантами. Положительные эмоции, сопровождающие совместную деятельность членов курсантского коллектива, являются важным аспектом становления курсантов как отдельной единицы целостной системы.

Процесс формирования межличностных отношений в курсантских подразделениях проходит по основным социально-психологическим закономерностям формирования любого коллектива, но с учетом своей специфики. Групповые процессы в курсантских подразделениях образуют многоуровневую структуру, ядром которой является совместная деятельность, обусловленная социально значимыми целями. Внутригрупповые отношения могут быть представлены в виде уважения или неуважения, доверия или недоверия, симпатий или антипатий, доброжелательности или недоброжелательности, удовлетворенности или неудовлетворенности, содействия или противодействия.

Мы провели исследование социально-психологических факторов, обусловленных совместной деятельностью курсантов академии ФГБОУ ВО Ивановской пожарно-спасательной академии ГПС МЧС России, которые оказывают отрицательное воздействие на их субъективную удовлетворенность.

Под субъективной удовлетворенностью курсантов будем понимать отношение реальности к ожиданиям курсантов от профессионально-служебных, бытовых и межличностных аспектов учебно-служебной деятельности. Причинами низкого уровня субъективной удовлетворенности будут либо неудовлетворенность адекватных потребностей курсантов, либо нереалистические, чрезмерно завышенные ожидания в отношении факторов учебно-служебной деятельности.

Исследование проводилось среди курсантов 1-го - 4-го года обучения Ивановской пожарно-спасательной академии ГПС МЧС России. Общая численность выборки составила 60 человек, возраст респондентов находился в интервале от 17 до 23 лет. Для исследования была разработана анкета, в которой курсантам было предложено проранжировать предложенные социально-психологические особенности совместной деятельности членов курсантского коллектива по уровню их влияния на их психологическое состояние обучающихся. Были перечислены следующие стрессфакторы, характерные для вузов МЧС России, которые курсанты должны были оценить: строгая регламентация распорядка дня; субординационный характер отношений; монотония теоретической учебной деятельности с переходом ее в длительный эмоциональный стресс в периоды экзаменационных сессий; высокая интенсивность и преимущественно формализованный характер социального 
взаимодействия в курсантском коллективе; относительная пространственная ограниченность жизнедеятельности и ограниченность разнообразия социальных связей; необходимость налаживать отношения с командирами отделений и заместителями командиров учебных групп (для младших командиров - с командованием курса); низкая культура общения и взаимоотношений среди курсантов; совмещение учебной деятельности с выполнением служебных обязанностей; привлечение к ликвидации последствий чрезвычайных ситуаций; преимущественно административно-командный стиль взаимоотношений офицеров - командиров курсантских подразделений и преподавателей с курсантами; личные антипатии и психологическая несовместимость с отдельными членами замкнутого коллектива; психологическую усталость от взаимодействия с ограниченным кругом людей.

Результаты работы позволили выделить следующие факторы учебно-служебной деятельности, которые, по мнению курсантов академии, приводят к высокому психологическому напряжению (Рис. 1):

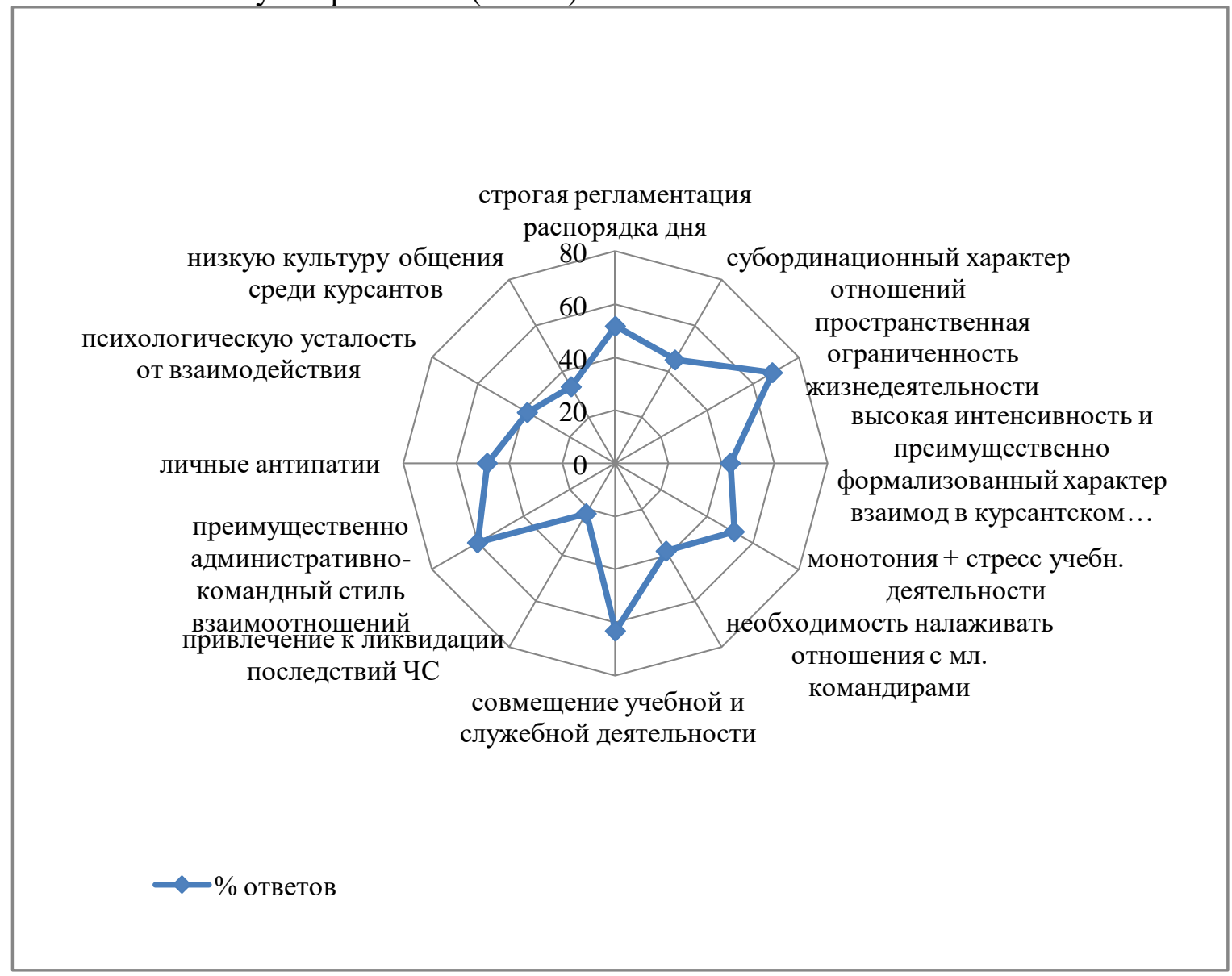

Рис. 1. Сравнение количества выборов по факторам учебно-служебной деятельности, вызывающих наибольшее психологическое напряжение у обучающихся, в \% (min=0; $\max =100)$

- 68,3 \% респондентов отметили, что наибольшую трудность в жизнедеятельности курсантов вызывает относительная пространственная ограниченность жизнедеятельности и ограниченность разнообразия социальных связей;

- $63,3 \%$ респондентов отметили сложность совмещения учебной деятельности с выполнением служебных обязанностей;

- $60 \%$ респондентов отметили, что испытывали затруднения в адаптации к преимущественно административно-командному стилю взаимоотношений офицеров - командиров курсантских подразделений и преподавателей с курсантами. 
Меньше всего трудностей учебно-служебной деятельности у курсантов академии вызывают следующие факторы:

- $22 \%$ - привлечение к ликвидации последствий ЧС (т.к. происходит редко и не носит массовый характер);

- 33,3\% - низкая культура общения и взаимоотношения среди курсантов;

- 38,3 \% - необходимость налаживать отношения с командирами отделений и заместителями командиров учебных групп;

- 38,3 \% - психологическая усталость от взаимодействия с ограниченным кругом людей.

Также анкета включала в себя ряд вопросов, направленных на выявление степени удовлетворенности курсантов учебно-служебной деятельностью в целом и субъективного мнения по вопросам психологического климата в их подразделении.

Проведенный корреляционный анализ (по критерию Пирсона - r) показал, что наибольшее отрицательное влияние на психологической комфорт у курсантов академии ГПС МЧС России оказывает фактор пространственной ограниченности жизнедеятельности (r= - 0.370, при $\mathrm{p} \leq 0.01)$. Необходимость постоянного взаимодействия курсантов в процессе обучения, несения службы и в быту может приводить к психологическому дискомфорту из-за невозможности иметь личное пространство.

Также была выявлена следующая интересная тенденция: курсанты, отметившие наличие сложности в совмещении учебной и служебной деятельности $(\mathrm{r}=0.299$, при $\mathrm{p} \leq$ $0.05)$, а также трудности адаптации к учебному стрессу $(\mathrm{r}=0.263$, при $\mathrm{p} \leq 0.05)$ проявляют большее желание в дальнейшей профессиональной деятельности занимать «командирские» должности. Это может быть связано с их ограниченным представлением о работе начальствующего состава.

Результаты работы также позволили установить обратно пропорциональную связь между наличием у курсантов большого круга дружеских связей и субординационным характером отношений в учебных подразделениях ГПС МЧС России $(\mathrm{r}=0.352$, при $\mathrm{p} \leq 0.01)$. Строго регламентированные отношения в вузах данного профиля позволяют говорить о наличии товарищества, необходимости поддерживать друг друга для качественной реализации деятельности всего подразделения. Однако более глубокие дружеские связи труднее обнаружить по нескольким причинам. Вопервых, часто учебно-служебные задачи могут входить в противоречие с принципами дружеских отношений. Во-вторых, обучающиеся после получения диплома направляются для прохождения службы в различные регионы страны. Существуют и другие причины, но для их конкретизации необходимо проводить дополнительные исследования.

Также стоит отметить, что курсанты, обучающиеся на выпускных курсах более «болезненно» относятся к наличию административно-командного стиля в отношениях с командирами курсов и преподавательским составам $(\mathrm{r}=0.351$, при $\mathrm{p} \leq 0.01)$. Это может быть связано с тем, что психологически старшекурсники чувствуют себя взрослыми и уверенными, а отношение к ним со стороны офицерского состава остается прежним, строго регламентированным. Их взрослеющее самовосприятие также подкрепляется получением на старших курсах первого офицерского звания младшего лейтенанта.

Далее мы рассмотрели взаимосвязи между факторами, усложняющими учебнослужебную деятельность. Обнаружили следующие закономерности:

1) Возможность курсантов участвовать в ликвидации последствий ЧС, позволяет курсантам приобрести необходимые профессиональные навыки и внести разнообразие в учебно-служебную деятельность $(\mathrm{r}=0.351$, при $\mathrm{p} \leq 0.01)$. Но стоит отметить, что участие в ликвидации крупномасштабных ЧС увеличивают вероятность возникновения стрессового состояния обучающихся. 
2) Строгая регламентация распорядка дня ( $\mathrm{r}=-0.346$, при $\mathrm{p} \leq 0.01)$ и субординационных характер отношений $(\mathrm{r}=-0.297$, при $\mathrm{p} \leq 0.05)$ позволяет снизить отрицательное влияние возникновения антипатий к сослуживцам. Однако необходимость совмещения учебной и служебной деятельности приводит к напряжению в межличностном взаимодействии $(\mathrm{r}=0.300$, при $\mathrm{p} \leq 0.05)$.

3) Психологическая усталость обучающихся от взаимодействия с ограниченным кругом людей приводит к снижению общей культуры общения и взаимоотношений среди курсантов $(\mathrm{r}=0.329$, при $\mathrm{p} \leq 0.05)$.

Групповые явления в учебных подразделениях ГПС МЧС России, отражающиеся во взаимоотношениях между курсантами, влияют на успешность реализации ими своих профессионально-служебных обязанностей. Выявление и обоснование маркеров негативных взаимоотношений в учебных подразделениях ГПС МЧС России может способствовать стабилизации межличностных отношений за счет целенаправленного применения психолого-педагогических, воспитательных и административных мер со стороны субъектов воспитательного воздействия.

Для того чтобы профилактическая работа имела дифференцированный характер, курсовым офицерам, как непосредственным организаторам воспитательной работы в учебной группе, необходимо обратить внимания на следующие ее направления: определение наиболее проблемных аспектов в работе каждого подчиненного подразделения; привлекать к работе по оптимизации взаимодействия в учебных подразделениях младших командиров всех уровней; систематически анализировать психологическое состояние и продуктивность учебного подразделения, по необходимости изменяя стратегию воспитательной работы [1].

$$
* * *
$$

1. Психология и педагогика. Военная психология: Учебник / Под ред. А.Г. Маклакова. — М., 2014. 464c.

2. Синеок В. В. Межличностные конфликты у курсантов и пути их разрешения: Дис. канд. психол. наук: 19.00.05: Москва, 1997, 240 с.

Шмырева О.И.

Эмоции в построении временной перспективы подростков

Воронежский государственный университет инженерных технологий (Россия, Воронеж)

doi 10.18411/gq-30-11-2017-25

idsp 000001:gq-30-11-2017-25

\section{Аннотация}

В статье представлены результаты исследования временной перспективы в подростковом возрасте через эмоциональное переживание продуктов творческой (художественной) деятельности Другого. Выявлены доминирующие факторы во временной перспективе в гендерных группах.

Ключевые слова: эмоции,подросток, временная перспектива.

Проблема соотношения прошлого, настоящего, будущего как естественно формируемого ритма, закладываемого в организацию жизнедеятельности человека, структурируется им самим и становится реальным отношением его к действительности своего временного бытия. Построение пространства отношений в перспективе и организационного плана оптимального содействия личности приобретает важное педагогическое значение. Играет ли роль в построении временной перспективы эмоциональный компонент? С какими периодами временной перспективы 